\title{
Nutrient concentration in tissue of the macroalga Enteromorpha as a function of nutrient history: an experimental evaluation using field microcosms
}

\author{
Peggy Fong ${ }^{1}$, Regina M. Donohoe ${ }^{2}$, Joy B. Zedler ${ }^{3}$ \\ ${ }^{1}$ Rosenstiel School of Marine and Atmospheric Sciences, Division of Marine Biology and Fisheries, University of Miami, \\ 4600 Rickenbacker Causeway, Miami, Florida 33149, USA \\ ${ }^{2}$ Department of Fisheries and Wildlife, Oregon State University, Corvallis, Oregon 97331, USA \\ ${ }^{3}$ Pacific Estuarine Research Laboratory, San Diego State University, San Diego, California 92182-0057, USA
}

\begin{abstract}
Nutrient enrichment experiments were conducted to assess the relationship between nutrient concentration in the tissue of the macroalga Enteromorpha sp. and nutrient history. Experimental units were outdoor microcosms containing mixed assemblages of algae representative of communities commonly found in coastal lagoons of southern California, USA. We determined the relationship between nutrient supply rates (nitrogen and phosphorus as well as N:P ratio), water-column nutrient concentrations, and macroalgal tissue nutrient concentration in samples taken from experimental microcosms containing macroalgae, phytoplankton, and cyanobacterial mats, and treated with 13 combinations of nitrogen and phosphorus addition. The regression coefficients that described the fit of the relationships between tissue $\mathrm{P}$ and both $\mathrm{P}$ supply rate and water-column concentration were greater than for the same relationships for $\mathrm{N}$. The relationship between tissue nutrients and either measure of nutrient history (water-column concentration or supply rate) was most useful when the nutrient was not limiting.
\end{abstract}

KEY WORDS: Tissue nutrients - Macroalgae - Enteromorpha sp. - Nitrogen · Phosphorus

\section{INTRODUCTION}

Nutrient supply sets the 'productivity potential' of algae in marine systems. If nutrients are limiting, nutrient availability will control algal productivity, abundance or biomass (for a review see Howarth 1988) and competition for nutrients can control algal community structure (Tilman \& Kilham 1976, Tilman 1977, Smith \& Horne 1988, Fong et al. 1993a). Nutrient enrichment may change community structure by favoring opportunistic algae with rapid nutrient uptake and growth potentials (Fujita 1985, Björnsäter \& Wheeler 1990. Fong et al. 1993b). Many foliose green macroalgae are adapted to survive in an uncertain environment, where nutrient supply is variable and unpredictable (Littler \& Littler 1980, Ramus \& Venable 1987, Duke et al. 1989). A simulation model of an algal community dominated by foliose green macroalgae (Fong et al. in press) based on physiological experiments (Fujita 1985, Wheeler \& Björnsäter 1992) and field surveys (Fong 1986, Rudnicki 1986, Wheeler \& Björnsäter 1992) suggests that the initial response of opportunistic green macroalgae to nutrient enrichment was to increase internal stores of nutrients. If so, then nutrient concentration in algal tissue may be a good indicator of nutrient enrichment (Bjornsäter \& Wheeler 1990) and the potential for future changes in the structure of macroalgal communities.

Nutrient enrichment of bays (Cambridge \& McComb 1984, Cambridge et al. 1986, Silberstein et al. 1986, Lapointe 1987, 1989), estuaries (Gordon et al. 1981, Day et al. 1989), and coastal water (Lapointe \& O'Connell 1989) is a major problem in many parts of the world. For many years, scientists have been trying to develop an effective indicator of nutrient enrichment that provides early warning and predicts the response 
of the ecosystem with a high level of accuracy (Shubert 1984). In many freshwater lakes in temperate zones, monitoring the magnitude of the phosphorus (P) maximum during spring turnover is a good indicator of the abundance of phytoplankton the following summer (Wetzel 1975). In some temperate estuaries, watercolumn $\mathrm{P}$ concentration in inflowing waters has been used to predict the phytoplankton abundance 'downstream' in the estuary (Lee \& Jones 1981).

Monitoring of water-column nutrient concentrations is the traditionally used method to indicate nutrient enrichment. However, in warm temperate (Fong et al. 1987, 1993a, b) and subtropical P. Fong \& M. E. Jacobson unpubl.) coastal ecosystems there is little correlation between water-column nitrogen $(N)$ or $P$ concentrations and either productivity or abundance of primary producers. In southern California (USA) lagoons and estuaries, nutrients are often supplied in pulses that are spatially and temporally variable (Peters et al. 1986); frequency and duration of these pulses depend on seasonal rainfall as well as unpredictable, but increasingly frequent, influxes of untreated wastewater. Although pulses of high nutrients produce transient peaks of water-column nutrients (Peters et al. 1986), unless loading rates are very high, nutrients do not accumulate in the water column (Fong et al. 1993b, in press). However, the macroalgal community responds by changing composition at lower nutrientsupply rates (Fong et al. in press). Thus, traditional methods of monitoring water-column nutrients to predict changing community structure may not be useful in warm temperate or subtropical coastal systems.

Monitoring the concentration of nutrients in the tissue of macroalgae may be a more useful indicator of enrichment or eutrophication potential. In order to develop this type of indicator, however, the relationship between tissue nutrients and nutrient history must be determined for a given alga. Macroalgae respond to nutrient enrichment by taking up nutrients, growing, and storing 'excess' nutrients for future growth (Hanisak 1979, Fujita 1985, Björnsäter \& Wheeler 1990). Thus, nutrient concentration in the algal tissue integrates the nutrient regime over some period of time (Wheeler \& Björnsäter 1992). Modeling of these 2 physiological processes suggests that this time is species specific and depends on the differences between maximum uptake and growth rates (Fong et al. in press). Many laboratory studies link nutrient uptake, tissue nutrient concentration, and growth for different species of macroalgae (Hanisak 1979. Wheeler \& North 1980, Rosenburg \& Ramus 1982, Lapointe \& Duke 1984, Fujita 1985). Results of both modeling and experiments suggest foliose green macroalgae may be an especially useful indicator for assessing nutrient enrichment as they are oppor- tunists with very fast nutrient uptake and growth rates, as well as a large internal storage capacity for nutrients (Waite \& Mitchell 1972, Birch et al. 1981, Gordon et al. 1981, Lapointe \& Tenore 1981, Duke et al. 1986, 1989).

Monitoring of tissue nutrients to detect enrichment could occur at less frequent intervals than monitoring of the water-column nutrients. A sequential enrichment/starvation study demonstrates that, following enrichment, internal stores of nutrients within the tissue of Enteromorpha spp. may not be depleted for up to 10 d (Fujita 1985). A simulation model of Enteromorpha spp. from lagoons in southern California suggests that the time lag between uptake and growth may be as long $20 \mathrm{~d}$ (Fong et al. in press).

Björnsäter \& Wheeler (1990) have demonstrated the relationship between both the concentrations of $N$ and $P$ as well as the N:P ratio in the tissue of the chlorophytic macroalgae Enteromorpha intestinalis and Ulva fenestrata grown in laboratory cultures and their nutrient status. Low $\mathrm{N}$ and either high or low $\mathrm{P}$ supply rates result in low concentrations of $\mathrm{N}$ in the tissue and low $\mathrm{N}$ : $\mathrm{P}$ ratios $(<16)$. Low $\mathrm{P}$ and high $\mathrm{N}$ supply rates result in low abundance of $\mathrm{P}$ and high $\mathrm{N}$ :P ratios (>24). High supplies of both nutrients result in high $\mathrm{N}$ and $\mathrm{P}$ tissue concentrations and intermediate $\mathrm{N}$ : P ratios (16 to 24). From these results, Björnsäter \& Wheeler (1990) suggest that monitoring of tissue $N$ and $P$ is a useful method of assessing the nutritional sufficiency of macroalgae, and use this method to determine the in situ nutritional status of 5 species of macroalgae common in Oregon (USA) coastal water (Wheeler \& Björnsäter 1992)

Using in situ microcosms, we determine the relationship between nutrient supply rates, water-column nutrient concentrations, and the $\mathrm{N}$ and $\mathrm{P}$ content and relative abundance in tissue of Enteromorpha putatively intestinalis from southern California lagoons. This microcosm experiment differs from the previous approach for determining nutritional status of macroalgae for several reasons. First, the microcosms contain a mixed assemblage of algae representative of coastal communities of primary producers in southern California. We use a mixed community to include interactions such as competition for nutrients or space among groups of primary producers that commonly co-exist. These interactions may influence the relationship between nutrient supply and tissue nutrients by changing the amount of nutrients available in the water column. Second, the microcosms are outdoors near the coast and therefore subject to more natural environmental variability than can be simulated in a laboratory. Third, although microcosms allow us to introduce more realistic environmental conditions, the nutrient supply rate can be carefully controlled. 


\section{METHODS}

Approach. We used the results of an enrichment experiment to determine which of several variables correlated with the concentration and relative abundance of $\mathrm{N}$ and $\mathrm{P}$ found in the tissue of Enteromorpha $\mathrm{sp}$. We assessed the relationship between nutrient supply rate, water-column nutrient concentration, and the concentration of nutrient in the tissue of Enteromorpha sp. for $\mathrm{N}, \mathrm{P}$, and the $\mathrm{N}$ : $\mathrm{P}$ ratio. Details of the design of the microcosm experiment are published elsewhere (Fong et al. 1993b) and summarized below.

Experimental design. Experimental microcosms were $100 \mathrm{l}$ plastic drums, $0.58 \mathrm{~m}$ in diameter and $0.64 \mathrm{~m}$ deep, lined with polyethylene bags and installed at the Pacific Estuarine Research Laboratory (PERL), an outdoor facility adjacent to the Tijuana estuary and north of the United States-Mexico border. Microcosms were open to the air but did not include sediment. Although sediments are very important to the nutrient budget of most coastal systems, acting as both sources and sinks of nutrients, we chose not to include sediments because we wanted to control the availability of inorganic nutrients to the algal community. With sediment, there would be concentrationdependent adsorption and desorption of nutrients that would affect availability; without sediments, the rate addition would reflect availability more closely. However, the influence of sediment on nutrient availability must be considered before applying the results of this experiment to real systems.

Microcosms were randomly selected and assigned to 13 treatments involving nutrient supply rates at $5 \mathrm{~N}: \mathrm{P}$ atomic ratios $(1: 1,5: 1,15: 1,30: 1$, and $60: 1)$ and up to 4 loading levels for each ratio (Table 1 ). There was also a control treatment with no nutrient addition. Due to time and budgetary constraints, only a subsection of treatments ( 9 of 13) was replicated to assess variability among microcosms. This partial replication resulted in 22 experimental units. The nutrient loading rates were representative of those measured monthly for $7 \mathrm{yr}$ entering 6 southern California lagoons (Peters et al. 1986). The ranges of $N$ and $P$ supply were very wide because nutrient supplies to these systems varied from low in natural stream flow to very high during influxes of wastewater. Nutrients often occurred as pulses, so we chose to add nutrients every third day.

On 13 July 1986, each microcosm was inoculated with macroalgae, cyanobacterial mats, and phytoplankton; this experiment lasted for $61 \mathrm{~d}$. One week before beginning the experiment, floating mats of the green macroalga Enteromorpha sp. and associated cyanobacterial mats were collected from San Elijo Lagoon, San Diego County, and placed in a holding pool filled with seawater. The day each experiment
Table 1. Experimental design of microcosm experiment. Thirteen treatments were administered in $5 \mathrm{~N}: \mathrm{P}$ ratios and up to 4 concentrations. Nutrients were added every $3 \mathrm{~d}$ at supply rates given (in $\mu \mathrm{M} 3 \mathrm{~d}^{-1}$ ). Numbers in parentheses are numbers of replicate microscosms for each treatment

\begin{tabular}{|c|c|c|c|c|c|}
\hline \multirow[t]{2}{*}{ Nutrient } & \multicolumn{5}{|c|}{$\mathrm{N}: \mathrm{P}$ ratio } \\
\hline & $1: 1$ & $5: 1$ & $15: 1$ & $30: 1$ & $60: 1$ \\
\hline$N$ & 1.00 & 1.25 & 3.75 & 30.00 & 15.00 \\
\hline $\mathrm{P}$ & $\begin{array}{c}1.00 \\
(2)\end{array}$ & $\begin{array}{c}0.25 \\
(2)\end{array}$ & $\begin{array}{c}0.25 \\
(2)\end{array}$ & $\begin{array}{l}1.00 \\
(2)\end{array}$ & $\begin{array}{l}0.2 \\
(2)\end{array}$ \\
\hline$N$ & 4.00 & 5.00 & 15.00 & 120.00 & 60.00 \\
\hline $\mathrm{P}$ & $\begin{array}{l}4.00 \\
(1)\end{array}$ & $\begin{array}{c}1.00 \\
(2)\end{array}$ & $\begin{array}{c}1.00 \\
(2)\end{array}$ & $\begin{array}{c}4.00 \\
(1)\end{array}$ & $\begin{array}{l}1.00 \\
\text { (1) }\end{array}$ \\
\hline $\mathrm{N}$ & 16.00 & 20.00 & & & \\
\hline $\mathrm{P}$ & $\begin{array}{c}16.00 \\
(1)\end{array}$ & $\begin{array}{c}4.00 \\
(2)\end{array}$ & & & \\
\hline $\begin{array}{l}\mathrm{N} \\
\mathrm{P}\end{array}$ & & $\begin{array}{c}80.00 \\
16.00 \\
(2)\end{array}$ & & & \\
\hline
\end{tabular}

was initiated, microcosms were filled with $85 \mathrm{l}$ of seawater from the Scripps Institution of Oceanography pier and $15 \mathrm{I}$ of freshwater from the city water supply to give a final salinity of $30 \mathrm{ppt}$. These water sources were chosen because they were accessible and representative of the source of water in the natural systems as coastal lagoons in southern California are bar-blocked marine embayments with periodic freshwater dilution. Salinity in each microcosm was monitored every third day, and we added approximately 1 to $2 \mathrm{l}$ of freshwater to maintain the salinity at $30 \pm 2 \mathrm{ppt}$

Each microcosm was inoculated with a $250 \mathrm{ml}$ sample of unfiltered water with phytoplankton from San Elijo Lagoon; initial chlorophyll a concentration in each microcosm was $1.82 \mu \mathrm{g} \mathrm{l}^{-1}(\mathrm{SE}=0.08)$. Initial chlorophyll values were within the range found in estuaries (Fong 1986) and lagoons (Peters et al. 1986) in southern California, though near the lower limit. Macroalgae and cyanobacterial mats were removed from the holding pool, blotted dry, and divided into $5 \mathrm{~g}$ (wet wt) subsamples that were added to each microcosm. Subsamples were homogeneous and within the range of abundance for these 2 groups of algae during the annual growing season (Rudnicki 1986). During the first $20 \mathrm{~d}$ of the experiment, growth rates of Enteromorpha sp. were relatively low, ranging from 0 to $5 \%$ $\mathrm{d}^{-1}$; after this initial lag phase, growth rates ranged from 2 to $75 \% \mathrm{~d}^{-1}$ (Fong et al. 1987). Although the macroalgae in all but the lowest nutrient treatments appeared green and healthy throughout the experiment, there was no simple relationship between addition rate or ratio and growth (Fong et al. 1993b). 
Fiberglass screening was placed over the tanks to reduce variability from colonizing insects. Screens attenuated approximately $30 \%$ of the photosynthetically active radiation. Samples taken from each microcosm at harvest had few species of animals, most of which were detritus feeders or microalgal scrapers (dominated by harpacticoid copepods: S. A. Por pers. comm.). Concentrated stock solutions of nitrate $\left(\mathrm{NaNO}_{3}\right)$ and orthophosphate $\left(\mathrm{NaHPO}_{4}\right)$ were added in appropriate amounts to each microcosm every third day. Contents were thoroughly mixed at this time. Temperatures of the mesocosms were similar to lagoon temperatures; afternoon readings ranged from 24 to $29^{\circ} \mathrm{C}$ with a diel change of 2 to $8^{\circ} \mathrm{C}$.

Water-column nutrient analysis. Every sixth day we sampled the water column and determined nutrient concentrations. Data are only shown for the final sampling date. To determine nutrient concentration, a $100 \mathrm{ml}$ water sample was taken from each microcosm after thorough mixing. In each case, nutrient sampling occurred prior to a scheduled nutrient addition, and therefore $3 \mathrm{~d}$ after the previous addition. Thus, nutrient concentrations represented the amount of nutrients that had accumulated or been depleted during the 3 d interval between additions. The samples were filtered in the field with Whatman GF/C glass fiber filters. The filtrate was collected, preserved with concentrated sulfuric acid $\left(2 \mathrm{ml} \mathrm{l}^{-1}\right)$, and stored at $4^{\circ} \mathrm{C}$ for no longer than $30 \mathrm{~d}$. Using a Technicon AutoAnalyzer II, the filtrate was analyzed for dissolved nitrate/nitrite (referred to as nitrate, Technicon 158-71W, 1977), orthophosphate (Technicon 155-71W, 1973), and ammonium (Technicon 154-71W, 1973). Use of GF/C filters probably resulted in low levels of ammonium contamination; however, this additional source of ammonium was constant for each sample, and so would not introduce variability or change the outcome of the regression or correlation analyses. Atomic $\mathrm{N}: \mathrm{P}$ ratios of the inorganic forms of nitrogen and phosphorus in the water column were calculated.

Tissue nutrient analysis. Tissues of Enteromorpha sp. were analyzed for total nitrogen and phosphorus concentration. At the end of the experiment, macroalgae were collected with a $5 \mathrm{~mm}$ mesh net for determination of tissue nutrient concentration. We removed the attached fauna, primarily brine fly larvae, and removed the blue-green algae that were mixed with Enteromorpha sp. in several treatments. Algae were briefly rinsed in freshwater, wrapped in aluminum foil, and placed in a forced air oven at $105^{\circ} \mathrm{C}$ until constant weight (about $72 \mathrm{~h}$; APHA 1980). Dried algae were sent to Environmental Engineering Laboratory, San Diego, CA, a state certified laboratory, where Technicon methods for total Kjeldahl nitrogen and total phosphate (\#329-74W) (Technicon AutoAnalyzer, Inc. 1977) were used to determine nutrient content.

\section{RESULTS}

\section{Tissue nitrogen content as an indicator of nutrient history}

Our first objective was to test if there were any relationships between nitrogen supply, water-column nitrogen concentration, and the amount of nitrogen in the tissue of Enteromorpha sp. Nitrogen is thought to be limiting in most warm temperate estuaries and coastal lagoons (Fong 1986, Day et al. 1989), and nitrogen was limiting in 10 of 13 of our experimental treatments, when supply rate was $\leq 60 \mu \mathrm{M} 3 \mathrm{~d}^{-1}$ (Fong et al. 1993b). We hypothesized that, in treatments where nitrogen was limiting, added nitrate would be removed rapidly, keeping water-column concentrations low. In all but one of the treatments, water-column nitrate concentrations were close to the daily loading concentrations (Fig. 1a), indicating that nitrate was removed as quickly as it was added. The exception was the experimental treatment where nitrate supply was $115.7 \mu \mathrm{M} 3 \mathrm{~d}^{-1}$. In this treatment, nitrate accumulated to $>780 \mu \mathrm{M}$ in the water, over 20 times the daily addition rate. In the other treatments, there was no pattern of increasing nutrients in the water as supply increased $\left(\mathrm{r}^{2}=0.11\right.$ for a linear regression).

There was a positive linear relationship between the nitrogen supply rate to each microcosm and the concentration of nitrogen in the tissue of Enteromorphasp. grown in a mixed algal community within the microcosm (Fig. $1 b ; r^{2}=0.43, p=0.0007$ ). However, when we removed the microcosms with nitrogen supply rates above saturation from the analysis, there was no relationship between nitrogen supply and tissue nitrogen $\left(\mathrm{r}^{2}<0.01\right)$. 'Luxury' consumption, or storage of nitrogen within the algal tissues prior to growth, occurred only in microcosms with the highest nitrogen supply rates. Therefore, there was only a relationship between supply and tissue concentration in the treatments where nitrogen was not limiting.

Tissue nitrogen concentrations were a function of the amount of nitrate in the water column (Fig. 1c). The relationship was asymptotic (logarithmic relationship; $\mathrm{r}^{2}=0.57$ ) at a tissue nitrogen concentration of ca $3.5 \%$. This may be the maximum storage capacity for nitrogen for Enteromorpha sp. in southern California lagoons. When we removed the treatments where nitrogen was not limiting, the best-fitting line was linear $\left(r^{2}=0.65 ; p=0.0002\right)$. Thus, when nitrogen was limiting, tissue nitrogen concentration was not a good indicator of nitrogen supply rate, but may be a useful indicator of water-column concentrations. When nitrogen was not limiting, the amount of 'excess' or stored nitrogen may be used as an indicator of both supplies and water-column nitrogen. 

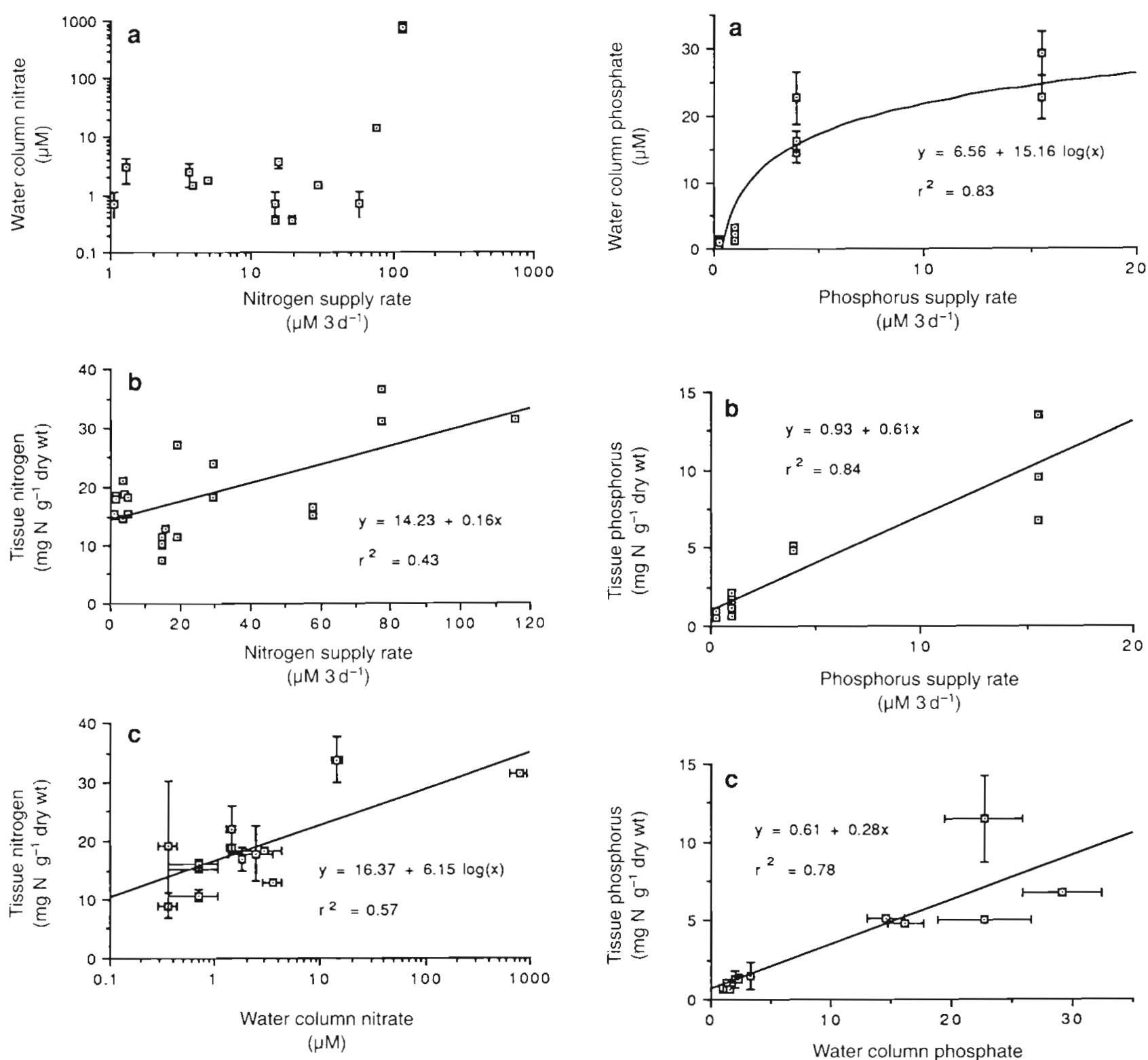

Fig. 1. Relationship between (a) $\mathrm{N}$ supply rate and watercolumn nitrate in experimental microcosms (bars: $\pm \mathrm{SE}_{;} \mathrm{n}=2$ ), (b) $\mathrm{N}$ supply rate and the amount of $\mathrm{N}$ in the tissue of Enteromorpha sp., and (c) water-column nitrate concentration (log scale) and tissue $\mathrm{N}$ in Enteromorpha sp. grown for $61 \mathrm{~d}$ in experimental microcosms with a mixed assemblage of algae (bars: $\pm \mathrm{SE}_{;} \mathrm{n}=2$ )

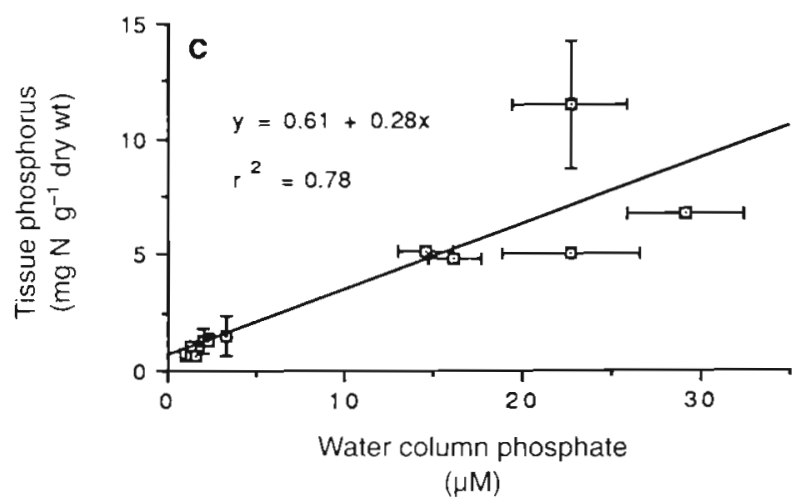

Fig. 2. Relationship between (a) P supply rate and water-column orthophosphate in experimental microcosms (bars: \pm SE; $\mathrm{n}=2$ ), (b) $\mathrm{P}$ supply and the amount of $\mathrm{P}$ in the tissue of Enteromorpha sp., and (c) water-column $\mathrm{P}$ concentration and tissue $\mathrm{P}$ in Enteromorpha sp. grown for $61 \mathrm{~d}$ in experimental microcosms (bars: $\pm \mathrm{SE}, \mathrm{n}=2$ )

\section{Tissue phosphorus as an indicator of nutrient history}

The relationship between phosphorus supply, watercolumn phosphorus concentration, and the amount of phosphorus in the tissue of Enteromorpha sp. was investigated. A hyperbolic relationship was the best fit between phosphorus supply and the amount of phosphorus in the water column (Fig. $2 \mathrm{a}_{i} \mathrm{r}^{2}=0.83$ ). Phos- phorus accumulation in the water column ranged from 5 to 20 times the daily loading rates, suggesting that phosphorus was never limiting. Growth rate and biomass data (Fong et al. 1993b) supported this conclusion. There was 'luxury' consumption of phosphorus, as phosphorus accumulated in the algal tissue in proportion to the supply rate (Fig. $2 b ; r^{2}=0.840, p=$ 0.0001 ). There was also a significant linear relationship 
between water-column phosphate and tissue phosphorus concentration (Fig. $2 c_{;} r^{2}=0.78, p=0.001$ ). Thus, in the non-limiting range of $\mathrm{P}$ supply that we tested, the amount of phosphorus that accumulated in the algal tissue was a good indicator of both water-column concentration and supply rate of phosphorus.

\section{Tissue $\mathrm{N}: \mathrm{P}$ ratio as an indicator of nutrient history}

There was a low, but significant, linear relationship $\left(r^{2}=0.24, p=0.03\right)$ between the $N: P$ ratio of the nutrient supply and the $N$ :P ratio of the nutrients measured in the water column $3 \mathrm{~d}$ after addition (Fig. $3 a$ ). Watercolumn N:P ratios ranged from 0.05 to 850 . When supply $N: P$ was $\leq 5, N$ was preferentially removed (N:P ratio lower in water than supply), with no pattern with the rate of addition. With a supply $\mathrm{N}: \mathrm{P} \geq 15$ the response bifurcated, with water-column ratios increasing greatly when nitrogen supply rate exceeded $0.270 \mathrm{mg}$ $\mathrm{N}^{-1} \mathrm{~d}^{-1}$ but low water-column ratios when supply rates were lower. Thus, it appears that there was a threshold supply rate and ratio above which inorganic nitrogen accumulated in the water column. However, the accumulation did not result in a water-column ratio that reflected the supply ratio.

The N:P ratio of the nutrient supply was not reflected in the $N: P$ ratio of the macroalgal tissue; the $r^{2}$ for linear regression was 0.07 ( $p=0.24$; Fig. $3 b$ ). There was considerable variability within treatments (coefficient of variation ranges from 5.7 to 60.0 ). The $\mathrm{N}: \mathrm{P}$ ratio in the algal tissue ranged from $4: 1$ to $75: 1$, with the maximum ratio occurning in algae from a treatment with a nutrient supply ratio of $5: 1$ and a low rate of addition.

There was not a significant relationship between the $\mathrm{N}: \mathrm{P}$ ratio in the water column and the $\mathrm{N}$ :P ratio in the algal tissue (Fig. $3 c_{i}$ line of best fit was logarithmic; $\mathrm{r}^{2}=$ $0.17)$. However, this relationship was strongly affected by a single datum with the highest water-column N:P ratio and a relatively low $\mathrm{N}$ :P tissue ratio; note that the $x$-axis is a log scale, and this water-column ratio is an order of magnitude greater than the others. This datum came from algae taken from a microcosm where nitrate accumulated in the water column. When we removed this point from the analysis, the relationship was significant (Fig. 3d; logarithmic; $\mathrm{r}^{2}=0.61$ ). With the one exception noted above, the maximum N:P ratio in the algal tissue exceeded 60:1 while the ratio in the
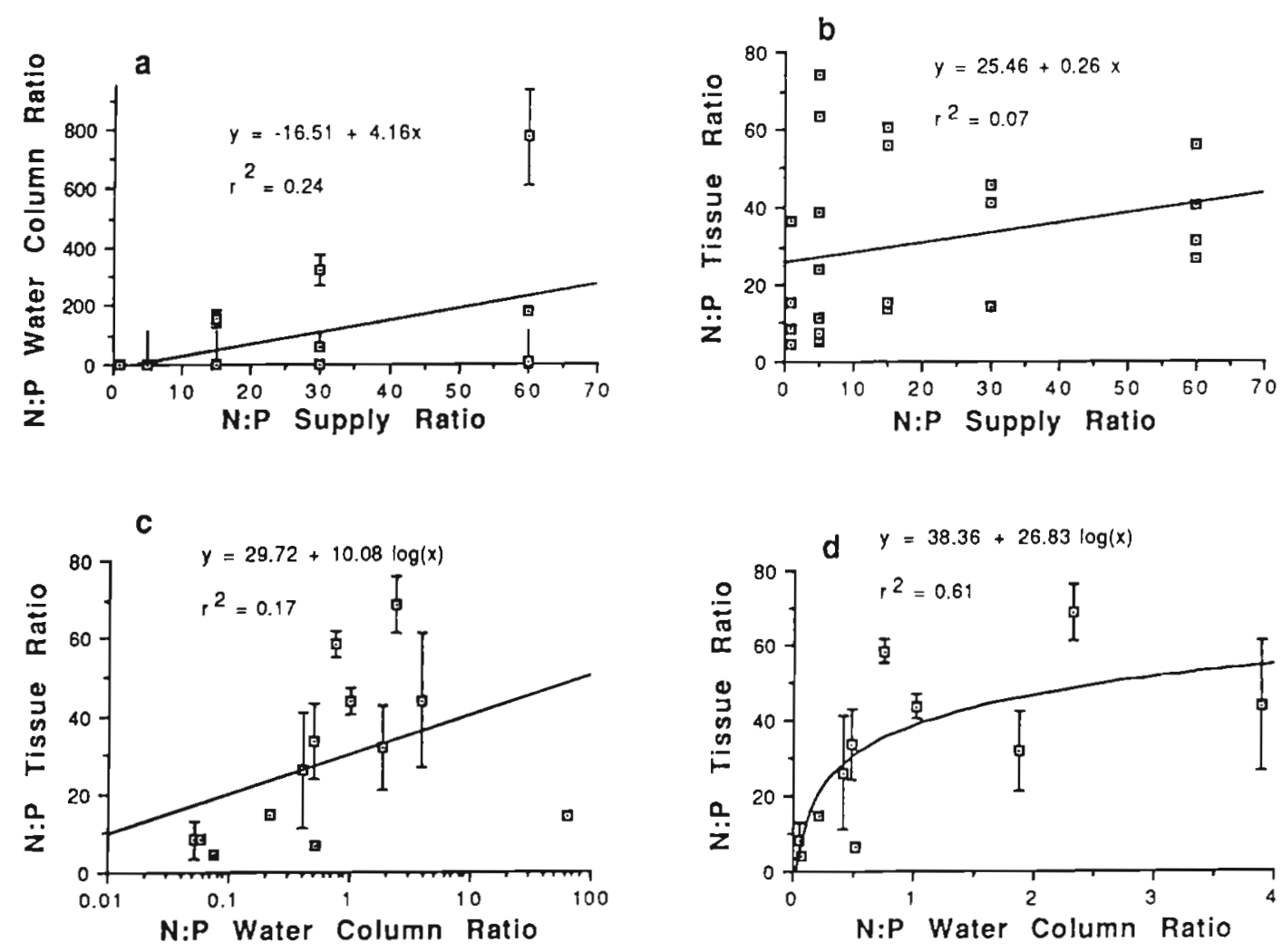

Fig. 3. Relationship between (a) nutrient supply ratio in the experimental treatments and in the water column at the end of the 61 d experiment and (b) N:P supply ratio and the nutrient ratio in the tissue of Enteromorpha sp. Water-column N:P ratio is related to the ratio found in the tissue of Enteromorpha sp. (c) with all 3 treatments, and (d) with the treatment with the highest nitrate supply rate eliminated. In (a), (c), and (d) values are means; bars: $\pm \mathrm{SE}_{i} \mathrm{n}=2$ 
water never exceeded $4: 1$. Thus, small changes in the water-column ratio resulted in large changes in the tissue $N$ :P. These results suggested that: (1) when nutrient supply saturated community uptake, the nutrient ratio in algal tissue was not an adequate indicator of the relative availability of nitrogen and phosphorus in the water column, and (2) Enteromorpha sp. preferentially removed nitrogen from the water.

\section{DISCUSSION}

The range of concentrations of $\mathrm{N}$ in the tissue of Enteromorpha sp. grown in our experimental microcosms (0.7 to $3.5 \%$ dry wt) compared to the range of $\mathrm{N}$ found for the genus Enteromorpha and other genera of green foliose macroalgae grown in laboratory cultures and collected from the field. The nitrogen content of $E$. intestinalis grown in laboratory cultures subjected to a wide range of $\mathrm{N}$ treatments ranged from 0.57 to $5.43 \%$ (Fujita 1985, O'Brien 1987, Björnsäter \& Wheeler 1990), while tissue samples from field populations collected along the Oregon Coast contained 2.0 to $5.5 \% \mathrm{~N}$ (Wheeler \& Björnsäter 1992). Ulva spp. had a similar range of $\mathrm{N}$ content in laboratory experiments, from 1.02 to $5.42 \%$ (Fujita 1985, Bjönsäter \& Wheeler 1990). When N pools within tissue of Ulva spp. were partitioned into inorganic and dissolved organic forms (Rosenburg \& Ramus 1982, Fujita et al. 1988), it was found that most of the non-structural $\mathrm{N}$ was stored as soluble organics. This result suggested that analysis of soluble organic $\mathrm{N}$ rather than total $\mathrm{N}$ may eliminate the need to establish a minimum $\mathrm{N}$ content for each indicator species. The minimum $\mathrm{N}$ content of Enteromorpha sp. in our experiment was similar to that found in the other studies, but the maximum $\mathrm{N}$ content was lower, despite the large amount of nitrogen available in the water column. This suggested that the Enteromorpha sp. in our experiment may not have had as large a maximum storage capacity for $\mathrm{N}$ as other species of foliose green macrophytes.

The concentration of tissue $\mathrm{P}$ in the Enteromorpha sp. from our microcosms $(0.08$ to $0.15 \%)$ fell within the lower portion of the range found in other nutrient experiments. E. prolifera contained from 0.10 to $0.33 \%$ dry wt $\mathrm{P}$ (O'Brien 1987) while Cladophora intestinalis treated with very high concentrations of $P$ contained $0.84 \%$ P (Schramm \& Booth 1981). Our values also compared to the lower ranges found in field populations of Ulva fenestrata and $E$. intestinalis collected along the coast of Oregon $(0.32$ to $0.86 \%$; Wheeler \& Björnsäter 1992), and Cladophora spp. from the Baltic $(0.07$ to $0.54 \%$; Wallentinus 1981), but exceeded the $P$ content of C. prolifera from Bermuda (Schramm \&
Booth 1981). Because the P content in our samples was relatively low despite accumulation of inorganic phosphorus in the water column, we suggest that Enteromorpha sp. from southern California lagoons may not have as high an affinity or as great a storage capacity for $P$ as other opportunistic green macroalgae.

The N:P ratios of Enteromorpha linza cultured in sewage-enriched seawater (38.7; Prince 1974) and field-collected samples of E. flexuosa (16; Atkinson \& Smith 1983) fell within the broad range of N:P ratios found in the tissue of Enteromorpha sp. in our microcosm experiment ( 3 to 75 ). Ranges of $\mathrm{N}: \mathrm{P}$ ratios in field-collected E. prolifera and Ulva fenestrata (10.1 to 29.3 and 11.2 to 30.1 , respectively; Wheeler \& Björnsäter 1992) were within our lower range, although experimental enrichment of laboratory cultures of $U$. fenestrata with high concentrations of nitrogen increased the ratio above 40 (Björnsäter \& Wheeler 1990). The highest ranges of $N: P$ ratios in the tissues of green foliose macroalgae were for both field populations ( 8 to 66; Wallentinus 1981) and laboratory cultures (4 to 42; Gordon et al. 1981) of Cladophora spp.

Our results showed that tissue $P$ concentrations may be used as an indicator of the $\mathrm{P}$ regime or $\mathrm{P}$ 'history' of Enteromorpha sp. grown in a mixed algal assemblage as long as $\mathrm{P}$ was not the limiting nutrient. In this experiment, the amount of $P$ that accumulated in the tissues integrated the pulsed supply rate as well as the amount of 'excess' $P$ that accumulated in the water column after the community nutrient demand was satisfied. Our results also suggested that the amount of $\mathrm{N}$ stored in the algal tissue may be used as an indicator of both supply and water-column $\mathrm{N}$ when $\mathrm{N}$ was not limiting. However, $N$ was only in excess in a subsection of our treatments and the relationship between tissue $\mathrm{N}$ and both water-column $\mathrm{N}$ and $\mathrm{N}$ supply rate was more variable than those for $\mathrm{P}$. This relationship may improve with sample size. When $\mathrm{N}$ was limiting, tissue $\mathrm{N}$ concentrations were not very useful indicators of $\mathrm{N}$ supply rate, and were only slightly better as indicators of water-column $\mathrm{N}$ concentrations.

The results of this experiment support the hypothesis that the concentrations of nutrients in the tissue of opportunistic macroalgae are a function of their nutrient history. We developed a conceptual model (Fig. 4) to summarize the relationships developed between tissue nutrients, nutrient limitation, water-column nutrient concentration, and nutrient supply rates. When the concentration of $\mathrm{N}$ or $\mathrm{P}$ in the tissue of a foliose green macroalga is low relative to the metabolic or structural demand, that nutrient limits biomass. When a nutrient is limiting, a transient relationship between the watercolumn and tissue concentration of that nutrient may be established. The strength of this relationship depends on whether sampling of water-column nutri- 


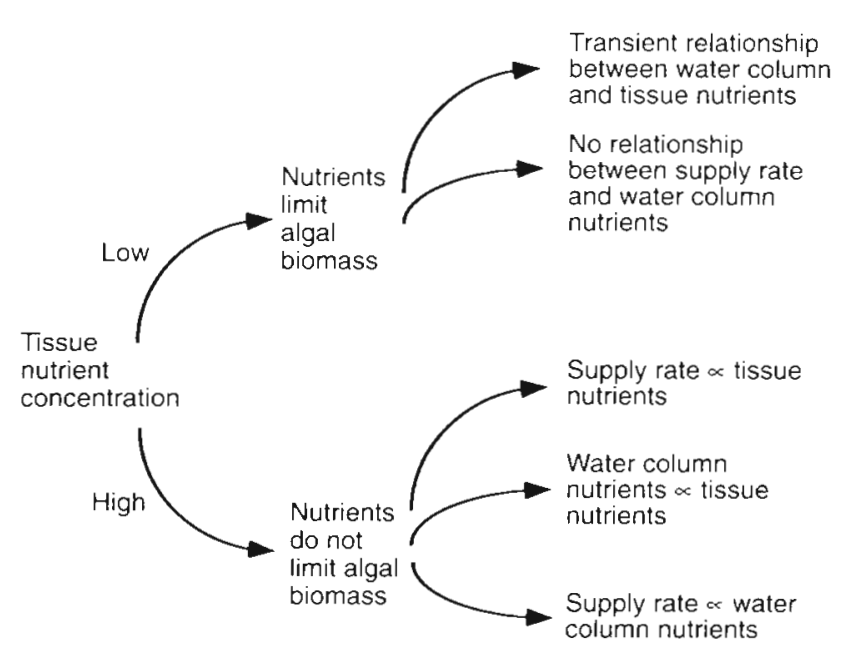

Fig. 4. Conceptual model summarizing the experimental results

ents is frequent enough to detect the transient peak in water-column nutrients between supply pulse and depletion through algal uptake. Thus, the water column must be sampled during the interval when uptake or assimilation rates rather than nutrients are limiting. Our results suggest that there is no relationship between supply rate and water-column nutrient concentration. Although, to be limiting, supply must remain below the maximum uptake of the algal community, it may vary considerably depending on the biomass and structure of the algal community. Watercolumn nutrients will be removed quickly in a community dominated by opportunists.

When nutrient concentration in the tissue of an opportunistic macroalgae is high relative to the minimum structural demand, then that nutrient is not limiting and there will be relationships between supply rate, tissue nutrients, and water-column nutrients (Fig. 4). Supply must exceed demand if a nutrient is not limiting, and water-column nutrients should be a function of supply. If nutrients are available in the water column in proportion to supply, then tissue nutrients should accumulate in proportion to both of these factors.

Acknowledgments. This research was funded, in part, by the Calitornia State Water Resources Control Board with grant funds made available by the United States Environmental Protection Agency and the San Diego Association of Governments. Additional support was provided by San Diego State University. The writing phase of this project was funded by a grant from the National Sea Grant College Program, National Oceanic and Atmospheric Administration, U.S. Department of Commerce, under grant number NA89AA-D-SG138, through the California Sea Grant College Graduate Research Fellowship Program. The views expressed herein are those of the authors and do not necessarily reflect the views of NOAA or any of its subagencies.

\section{LITERATURE CITED}

American Public Health Association (APHA) (1980). Standard methods for the examination of water and wastewater American Public Health Association, Washington, DC

Atkinson, M., Smith, S. V. (1983). C:N:P ratios of benthic marine plants. Limnol. Oceanogr. 28: 568-574

Birch, P. B., Gordon, D. M., McComb, A. J. (1981). Nitrogen and phosphorus nutrition of Cladophora in the PeelHarvey estuarine system, western Australia. Botanica mar. 24: $381-387$

Björnsäter, B. R., Wheeler, P. A. (1990). Effect of nitrogen and phosphorus supply on growth and tissue composition of Ulva fenestrata and Enteromorpha intestinalis (Ulvales, Chlorophyta). J. Phycol. 26: 603-611

Cambridge, M. L., Chiffings, A. W., Brittan, C., Moore, L., McComb, A. J (1986). The loss of seagrass in Cockburn Sound, Western Australia. II. Possible causes of seagrass decline. Aquat. Bot. 24: 269-285

Cambridge, M. L., McComb, A. J. (1984). The loss of seagrass in Cockburn Sound, Western Australia. I. The time course and magnitude of seagrass decline in relation to industrial development. Aquat. Bot. 20: 229-243

Day, J. W. Jr, Hall, C. H. S, Kemp, W., Yanez-Arancibia, A (1989). Estuarine ecology. John Wiley and Sons, New York

Duke, C. S., LaPointe, B. E., Ramus, J. (1986). Effects of light on growth, RuBPCase activity and chemical composition of Ulva species (Chlorophyta). J. Phycol. 22: 362-370

Duke, C. S., Litaker, W., Ramus, J. (1989). Effect of temperature, nitrogen supply, and tissue nitrogen on ammonium uptake rates of the Chlorophyte seaweeds Ulva curvata and Codium decorticatum. J. Phycol. 25: 113-120

Fong, P. (1986). Monitoring and manipulation of phytoplankton dynamics in a southern California estuary. M.Sc. thesis, San Diego State University

Fong, P., Donohoe, R. M. Zedler, J. B. (1987). Algal community response to nitrogen and phosphorus loadings in experimental mesocosms: management recommendations for southern California coastal lagoons. Report prepared for the Regional Water Quality Control Board with EPA funds. San Diego Regional Government, San Diego

Fong, P., Donohoe, R. M., Zedler, J. B. (1993a). Competition with macroalgae and benthic cyanobacterial mats limits phytoplankton abundance in experimental microcosms. Mar. Ecol. Prog. Ser 100: 97-102

Fong, P., Foin, T C., Zedler, J. B. (in press). A simulation model of lagoon algal communities based on competition for nitrogen and internal storage. Ecology

Fong, P., Zedler, J. B., Donohoe, R. M. (1993b). Nitrogen vs. phosphorus limitation of algal biomass in shallow coastal lagoons. Limnol. Oceanogr. 38: 906-923

Fujita, R. M. (1985). The role of nitrogen status in regulating transient ammonium uptake and nitrogen storage by macroalgae. J. exp. mar. Biol. Ecol. 92: 283-301

Fujita, R. M., Wheeler, P. A., Edwards, R. L. (1988). Metabolic regulation of ammonium uptake by Ulva rigida (Chlorophyta): a compartmental analysis of the rate-limiting step for uptake. J. Phycol. 23: 560-566

Gordon, D. M., Birch, P. B., McComb, A. J. (1981). Effects of inorganic phosphorus and nitrogen on the growth of an estuarine Cladophora in culture. Botanica mar. 24: $93-106$

Hanisak, M. D. (1979). Nitrogen lumitation of Codium fragile ssp. tomentosoides as determined by tissue analysis. Mar Biol. 50: 333-337

Howarth, R. W. (1988). Nutrient limitation of net primary production in marine systems. Ann. Rev. Ecol. 19: 89-110 
Lapointe, B. E. (1987). Phosphorus- and nitrogen-limited photosynthesis and growth of Gracilaria tikvahiae (Rhodophyceae) in the Florida Keys: an experimental field study. Mar. Biol. 93: 561-568

Lapointe, B. E. (1989). Macroalgal production and nutrient relations in oligotrophic areas of Florida Bay. Bull. mar. Sci. 44: 312-323

Lapointe, B. E., Duke, C. S. (1984). Biochemical strategles for growth of Gracilaria tikvahiae (Rhodophyceae) in relation to light intensity and nitrogen availability. J. Phycol. 20: $488-495$

Lapointe, B. E., O'Connell, J. (1989). Nutrient-enhanced growth of Cladophora prolifera in Harrington Sound, Bermuda: eutrophication of a confined, phosphorus-limited marine ecosystem Estuar. coast. Shelf Sci. 28: 347-360

Lapointe, B. E., Tenore, K. R. (1981). Experimental outdoor studies with Ulva fasciata Delile. I. Interactions of light and nitrogen on nutrient uptake, growth, and biochemical composition. J. exp. mar. Biol. Ecol. 53: 135-152

Lee, G. F., Jones, R. A. (1981). Application of the OECD eutrophication modeling approach to estuaries. In: Neilson, B. J., Cronin, L. E. (eds.) Estuaries and nutrients. Humana Press, Clifton, NJ, p. 540-568

Littler, M. M., Littler, D. S. (1980). The evolution of thallus form and survival strategies in benthic marine macroalgae: field and laboratory tests of a functional form model. Am. Nat. 116: 25-44

O'Brien, M. C. (1987). Nitrogen and phosphorus uptake by Enteromorpha prolifera (Mull.) J. Ag. M.S. thesis, Oregon State University, Corvallis

Peters, G., Paznokas, W., Noyes, V. (1986). A review of nutrient standards for the coastal lagoons in the San Diego region. San Diego Region Report, Califorma Regional Water Quality Control Board, San Diego

Prince, J. S. (1974). Nutrient assimilation and growth of some seaweeds in mixtures of seawater and secondary sewage treatment effluents. Aquaculture 4: 69-79

Ramus, J., Venable, M. (1987). Temporal ammonium patchiness and growth rate in Codium and Ulva (Ulvophyceae). J. Phycol. 23: 518-523

Rosenburg, G., Ramus, J. (1982). Ecological growth strategies in the seaweeds Gracilaria folifera (Rhodophyceae) and Ulva sp. (Chlorophyceae): soluble nitrogen and reserve carbohydrates. Mar. Biol. 66: 251-259

This article was presented by J. S. Pearse, Santa Cruz, California, USA
Rudnicki, R. M. (1986). Dynamics of macroalgae in Tijuana Estuary: response to simulated wastewater addition. M.Sc. thesis, San Diego State University

Schramm, W., Booth, W. (1981). Mass bloom of the alga Cladophora prolifera in Bermuda: productivity and phosphorus accumulation. Botanica mar. 24: 419-426

Shubert, L. E. (1984). Algae as ecological indicators. Academic Press, London

Silberstein, K., Chiffings, A. W., McComb, A. J. (1986). The loss of seagrass in Cockburn Sound, Western Australia. III. The effects of epiphytes on productivity of Posidonia australis Hook. F. Aquat. Bot. 24: 355-371

Smith, D. W., Horne, A. J. (1988). Experimental measurement of resource competition between planktonic microalgae and macroalgae (seaweeds) in mesocosms simulating the San Francisco Bay-Estuary, California. Hydrobiologia 159: $259-268$

Technicon Autoanalyzer, Inc. (1977). Individual/simultaneous determination of nitrogen and/or phosphorus in $\mathrm{BD}$ acid digests, industrial method No. 329-74W. Technicon Autoanalyzer, Inc., Terrytown, NY

Tilman, D. (1977). Resource competition between planktonic algae: an experimental and theoretical approach. Ecology 58: $338-348$

Tilman, D., Kilham, S. S. (1976). Phosphate and silicate growth and uptake kinetics of the diatoms Asterionella formosa and Cyclotella meneghiniana in batch culture and semicontinuous culture. J. Phycol. 12: 375-383

Waite, T., Mitchell, R. (1972). The effect of nutrient fertilization on the benthic alga Ulva lactuca. Botanica mar. 15: $151-156$

Wallentinus, I. (1981). Chemical constituents of some baltic macroalgae in relation to environmental conditions. Proc int. Seaweed Symp. 10: 363-370

Wetzel, R. G. (1975). Limnology. W. B. Saunders Company, Philadelphia

Wheeler, P. A., Björnsäter, B. R. (1992). Seasonal fluctuations in tissue nitrogen, phosphorus, and $\mathrm{N}: \mathrm{P}$ for five macroalgal species common to the Pacific northwest coast J. Phycol. 28: 1-6

Wheeler, P. A., North, W. J. (1980). Effect of nitrogen supply on nitrogen content and growth rate of juvenile Macrocystis pyrifera (Phaeophyta) sporophytes. J. Phycol. 16: $77-82$

Manuscript first received: July 6, 1993

Revised version accepted: December 16, 1993 